\title{
PREFERENSI MUSIK DI KALANGAN REMAJA
}

\author{
Ayub Prasetiyo \\ Dosen tetap Jurusan Musik, FSP ISI Yogyakarta. \\ Email: biru_bening@yahoo.co.id.; Telp. +62818274677
}

\begin{abstract}
The main purpose of this study is to understand the interest trend of music preference among youths as well as to analyse factors that influence the trend. Although qualitative method was used, this study utilized questioner for its data collecting technique. The collected data was analyzed to gather respondents's point of views and answers concerning music that they like. This study conclude that music interest trend among youth is mostly to popular music. Although the music has taken the highest rank position, its supporters are not only listen to their main preference but also other musical styles. Youths's tendency to choose popular music have been based on several factors such as, the objective value of the music, the capability of the music to represent conditions that are experienced by them, as well as musical meaning among the youths.
\end{abstract}

Keywords: Music preference, popular music, youths

\begin{abstract}
Abstrak
Penelitian ini terutama bertujuan untuk memahami kecenderungan preferensi selera musik di kalangan remaja dan untuk menganalisis faktor-faktor yang mempengaruhi kecenderungan tersebut. Metode yang digunakan dalam penelitian ini adalah metode kualitatif dengan teknik pengumpulan data melalui kuesioner. Kuesioner digunakan untuk untuk memperoleh pandangan serta jawaban responden tentang pilihan musik mereka. Studi ini menemukan bahwa walaupun minat terhadap musik pop menempati ranking teratas, mereka juga 'mengkonsumsi' jenis-jenis musik lain. Kecenderungan pemilihan musik pop sebagai preferensi di kalangan remaja dilatarbelakangi oleh beberapa faktor, yaitu nilai objektif dari musik pop itu sendiri, kemampuan musik pop untuk merepresentasikan kondisi-kondisi yang dialami olah remaja, serta makna dari musik itu bagi kalangan remaja.
\end{abstract}

Kata Kunci: Preferensi musik, musik populer, remaja

\section{Pengantar}

Bagaimana preferensi atau selera musik di kalangan remaja? Faktor apa yang mempengaruhi preferensi musik di kalangan remaja? Kondisi kehidupan dewasa ini, yang seolah Kebarat-baratan, cukup tampak jelas dalam pola perilaku remaja masa kini. Tidak hanya dalam selera musik, kecenderungan ini juga tampak antara lain pada fashion, tatanan rambut, gaya berbicara, bahkan pola pergaulan yang terkesan sangat bebas. Mengapa pola-pola seperti ini terbentuk? Atau, mengapa remaja dekat dengan media-media ini-musik tertentu, fashion tertentu, dan lainnya-dalam pola hidup keseharian mereka? Berkenaan dengan musik, Paul Willis dalam 
karangannya yang berjudul Profan Culture (1978), misalnya, menunjukkan beberapa faktor yang melatarbelakangi penggunaan musik atau preferensi musik Rock n' Roll dalam komunitas Motorbike Boys. Willis (1978: 62-63) mendapati bahwa preferensi musik ini disebabkan karena Rock n' Roll memiliki 'kapasitas dialektis suatu nilai real Motorbike Boys', serta kemampuan untuk memberikan perasaan akan 'keamanan, autentisitas, dan maskulinitas'. Berdasarkan contoh ini, muncul pertanyaan apa latar belakang serta orientasi terkait kecenderungan preferensi musik di kalangan remaja?

Literatur-literatur yang memuat permasalahan kecenderungan selera musik pada kalangan-kalangan tertentu secara khusus (misalnya kalangan remaja) sejauh ini belum ditemui. Kendatipun demikian, karangan Pierre Bourdieu yang berjudul Distinction: A Sosial Critique of the Judgement of Taste (1984) memuat faktor-faktor apa yang mempengaruhi selera (taste), termasuk selera akan seni. Dalam buku ini, Bourdieu memaparkan pula tentang kecenderungan selera musik, dan ternyata, preferensi musik menjadi salah satu identitas dari kelas-kelas sosial yang ada. Dengan kata lain, jenis musik tertentu diasosiasikan dengan kelas sosial tertentu. Temuan inilah yang antara lain memunculkan permasalahan dalam studi ini. Selain itu, karangan Bourdieu ini kiranya juga berguna untuk mengupas fenomena kecenderungan musik di kalangan remaja yang merupakan objek dari studi ini.

Karangan Bourdieu yang disebut di atas tampaknya masih menjadi acuan utama dalam studistudi serta pemicu berbagai pertanyaan atau gagasan terkait selera musik. Salah satu buku yang mengkaji kembali kecenderungan preferensi musik masyarakat dan hubungannya dengan kelas sosial adalah Culture, Class, Distinction (Bennett dkk., 2009). Dalam bab 5, disajikan hasil studi Bennet dan rekan-rekannya yang melibatkan sejumlah responden yang berasal dari berbagai strata sosial, etnis, bangsa, dan gender untuk meihat kecenderungan selera musik. Hal yang menarik adalah temuan adanya kecenderungan selera musik yang heterogen dalam kategori sosial tertentu. Kecenderungan pengkonsumsian beraneka warna jenis musik oleh satu kategori sosial tertentu ini disebut dengan omnivora musik. Hal ini memunculkan pertanyaan, yakni, benarkah preferensi musik menunjukkan kategori sosial tertentu yang memiliki habitus tertentu? Jika ya, mengapa satu kategori sosial memiliki kecenderungan preferensi musik yang beragam, seperti temuan dari studi yang dilakukan Bennett dan rekanrekannya? Hal ini juga menjadi salah satu pemicu munculnya gagasan pokok dalam penelitian yang akan dilakukan ini.

Buku karangan James J. Nott yang berjudul Music for the People: Popular Music and Dance in Interwar Britain (2002), membahas permasa- 
lahan selera dalam musik populer di Inggris antara tahun 1918-1939 secara khusus pada bab 8 (pp. 193-225). Nott menunjukkan adanya pengarus ideologi agama saat itu, yakni katolisitas, terkait dengan kecenderungan selera musik. Hal ini menunjukkan bahwa kekuatan penguasa dalam bentuk apapun dapat mempengaruhi kecenderungan selera musik. Kendatipun demikian, Nott tidak hanya berhenti pada permasalahan tersebut. Ia melanjutkan untuk menganalisis keterkaitan antara lirik-lirik dan isi dari lagu, dan ia mendapati kecenderungan bahwa kelas sosial tertentu memiliki preferensi jenis musik tertentu. Nott menunjukkan bahwa musik klasik terutama diminati oleh masyarakat kelas menengah, sedangkan mereka yang termasuk dalam golongan kelas pekerja, preferensi musiknya cenderung mengarah pada musik jazz. Ia juga menunjukkan kecenderungan preferensi musik berdasarkan usia. Musik jazz umumnya digandrungi oleh mereka yang berusia antara 15-35 tahun, sedangkan musik klasik memiliki peminat hampir merata dari berbagai latar belakang usia. Akhirnya, Nott mengemukakan bahwa selera musik, dalam hal ini musik populer, juga turut dibentuk oleh industri musik populer. Meskipun masyarakat bebas untuk memilih musik yang mereka sukai, selera musik masyarakat belakangan ini semakin dipengaruhi oleh kebijakan prouksi dari perusahaanperusahaan rekaman. Bentuk-bentuk pembatasan lewat sensor dan aturanaturan tertentu menunjukkan bahwa perusahaan-perusahaan tersebut melakukan 'sanitasi' terhadap musik populer, sekaligus melakukan standarisasi terkait musik apa yang didengarkan oleh masyarakat (Nott, 2002: 225). Jika dicermati, fenomena demikian juga terjadi di Indonesia dewasa ini. Popularisasi jenis musik tertentu agaknya memungkinkan terjadinya standarisasi selera musik masyarakat, atau standarisasi selera musik dari kategori masyarakat tertentu-berlawanan dengan temuan adanya kecenderungan omnivora musik. Hal ini kiranya perlu untuk dicermati, seperti halnya yang akan dilakukan dalam penelitian ini.

Penelitian ini terutama bertujuan untuk memahami kecenderungan selera musik atau preferensi musik di kalangan remaja dan untuk menganalisis faktor-faktor apa saja yang kiranya mempengaruhi kecenderungan selera atau preferensi musik.

Metode yang digunakan dalam penelitian ini adalah metode kualitatif. Kendatipun demikian, pengumpulan data dilakukan dengan teknik yang umum digunakan dalam penelitian kuantitatif, yakni kuesioner. Kuesioner yang digunakan tidak dimaksudkan untuk dianalisis kuantitasnya, melainkan untuk memperoleh pandangan serta jawaban dari para responden tentang musik yang mereka sukai. Penggunaan kuesioner ditempuh sebab jumlah responden cukup besar, dan tidak memung- 
kinkan untuk dilakukan wawancara mendalam (in-depth interview). Penggunaan kuesioner dalam penelitian ini dirancang sedemikian rupa agar informasi yang diperoleh dari responden cukup mendalam, yakni dengan cara penyusunan pertanyaan yang diajukan secara sistematis (untuk lebih rinci, lihat lampiran).

Kuesioner digunakan untuk mengumpulkan data guna menjawab permasalahan bagaimana kecenderungan selera musik di kalangan remaja, atau musik apa yang paling digandrungi oleh kalangan remaja dewasa ini. Selanjutnya, hasil yang diperoleh dari kuesioner ini akan dinalisis secara interpretatif guna menjawab permasalahan selanjutnya, yakni faktor-faktor apa yang mempengaruhi kecenderungan selera musik di kalangan remaja. Jika hasil kuesioner menunjukkan bahwa musik poplah yang digandrungi, misalnya, maka faktor-faktor apa yang menyebabkan musik pop disukai? Apakah karena liriknya yang dekat dengan kondisi kehidupan sehari-hari remaja?

Responden yang dijadikan sasaran atau subjek penelitian (yang nantinya akan mengisi pertanyaanpertanyaan dalam kuesioner) adalah para pelajar yang duduk di bangku SMA dari sekolah tertentu yang ada di Yogyakarta (Sekolah Menengah Musik dan Sekolah Menengah Umum). Jumlah responden dalam penelitian ini adalah 139 orang, yang secara garis besar berbeda latar belakang pendidikan. Responden dengan latar belakang sekolah kejuruan musik berjumlah 68 orang dan latar belakang sekolah menengah umum berjumlah 71 orang.

Mengapa pelajar SMA yang dipilih sebagai objek? Hal ini didasari oleh paling tidak dua alasan pokok. Pertama, secara psikologis, yang dikategorikan sebagai remaja adalah mereka yang berusia antara 14-17 tahun (Kartono, 2007). Kedua, pelajar (dalam penelitian ini, mereka yang duduk di Bangku SMA) lebih terorganisasi dengan baik, terutama berkaitan dengan usia (yang dikategorikan sebagai remaja). ${ }^{1} \quad$ Sebagai sampel, masing-masing tingkatan akan diambil satu kelas. Satu kelas untuk tingkat/kelas $X$, satu kelas untuk tingkat/kelas XI, dan satu kelas untuk tingkat/kelas XII. Hal ini dimaksudkan agar teba usia yang ada dapat tercakup, namun tidak begitu menyulitkan peneliti karena banyaknya jumlah responden yang harus disertakan jika semua kelas dalam masing-masing tingkatan dijadikan sampel.

Ada dua jenis sekolah yang siswanya dijadikan sampel dalam penelitian ini, yakni sekolah umum dan sekolah kejuruan musik. Hal ini dimaksudkan agar diperoleh pemahaman yang lebih mendalam terkait persepsi seseorang terhadap musik berkenaan dengan lingkup sosialisasinya. Siswa di sekolah-sekolah umum biasanya memiliki tingkat interaksi (terhadap musik) yang berbeda dengan siswa di sekolah kejuruan musik. Selain itu, jenis musik 
yang dekat dengan masing-masing kategori siswa berdasarkan sekolah (sekolah umum dan sekolah kejuruan musik) tampaknya berbeda.

Selanjutnya, data yang diperoleh dari para siswa dengan sekolah yang berbeda akan dianalisis dalam kerangka komparaif. Perbandingan ini tidak dimaksudkan untuk menunjukkan kelebihan salah satunya (siswa dalam sekolah umum atau sekolah kejuruan musik), maupun kekurangan dari yang lainnya, namun, untuk memperoleh pemahaman terkait kondisi lingkungan dan pengaruhnya terhadap persepsi dan preferensi para siswa tersebut. Untuk lebih jelas tentang proses penelitian ini, perhatikan bagan berikut.

\section{Pembahasan}

Data yang dikumpulkan dalam penelitian ini secara garis besar diklasifikasikan menjadi dua bagian, yakni data yang diperoleh dari responden yang berasal dari sekolah kejuruan musik (SMKN 2 Kasihan, Bantul, atau yang dahulu dikenal dengan SMM Yogyakarta) dan dari sekolah menengah umum (SMU Muhammadiyah 2 Yogyakarta). Responden yang berasal dari sekolah kejuruan musik meliputi setiap tingkatan kelas, dengan masingmasing tingkatan terdiri atas jumlah yang berbeda-beda.
Tabel 1. Jumlah Responden Sekolah Kejuruan Musik

\begin{tabular}{|l|l|l|}
\hline \multicolumn{1}{|c|}{ Kategori } & \multicolumn{1}{c|}{ Jumlah } & \multicolumn{1}{c|}{ Persentase } \\
\hline Total & 68 orang & Whole $(100 \%)$ \\
\hline Laki-laki & 37 orang & $54,41 \%$ \\
\hline Perempuan & 31 orang & $45,58 \%$ \\
\hline
\end{tabular}

Dari total jumlah 68 orang responden ${ }^{2}$ yang berasal dari sekolah menengah kejuruan musik, ditemukan bahwa genre musik pop menempati posisi teratas. Dengan kata lain, kecenderungan preferensi mengarah pada musik pop, disusul oleh genre rock, klasik, jazz, keroncong, tradisional, dan campursari. Untuk lebih jelasnya, perhatikan tabel di bawah ini.

Tabel 2. Preferensi Genre Musik Responden Sekolah Kejuruan Musik

\begin{tabular}{|l|l|l|}
\hline Genre & Jumlah & Persentase \\
\hline Pop & 35 orang & $51,47 \%$ \\
\hline Rock & 20 orang & $29,41 \%$ \\
\hline Keroncong & 5 orang & $7,35 \%$ \\
\hline Campursari & 2 orang & $2,94 \%$ \\
\hline Tradisional & 3 orang & $4,41 \%$ \\
\hline Jazz & 15 orang & $22,05 \%$ \\
\hline Klasik & 16 orang & $23,52 \%$ \\
\hline Genre lain & & \\
\hline Ska \& pop rock & 2 orang & $2,94 \%$ \\
\hline Pop alternatif & 1 orang & $1,47 \%$ \\
\hline $\begin{array}{l}\text { Deathmetal, } \\
\text { metalcore, } \\
\text { southernrock, } \\
\text { Christian rock, } \\
\text { screamd, Sweetcore }\end{array}$ & 1 orang & $1,47 \%$ \\
\hline Punk & 2 orang & $2,94 \%$ \\
\hline Post punk & 1 orang & $1,47 \%$ \\
\hline Metal & 3 orang & - \\
\hline Instrumental & 1 orang & $1,47 \%$ \\
\hline Blues & 1 orang & $1,47 \%$ \\
\hline Easy listening & 1 orang & $1,47 \%$ \\
\hline reggae & 1 orang & $1,47 \%$ \\
\hline Progresif rock & 1 orang & $1,47 \%$ \\
\hline
\end{tabular}


Sama halnya dengan responden di sekolah kejuruan musik, responden yang berasal dari sekolah menengah umum meliputi setiap tingkatan kelas, dengan masingmasing tingkatan terdiri atas jumlah yang berbeda-beda.

Tabel 3. Jumlah Responden Sekolah Menengah Umum

\begin{tabular}{|l|l|l|}
\hline \multicolumn{1}{|c|}{ Kategori } & \multicolumn{1}{c|}{ Jumlah } & \multicolumn{1}{c|}{ Persentase } \\
\hline Total & 71 orang & Whole $(100 \%)$ \\
\hline Laki-laki & 25 orang & $35,21 \%$ \\
\hline Perempuan & 46 orang & $64,79 \%$ \\
\hline
\end{tabular}

Dari total jumlah 71 orang responden yang berasal dari sekolah menengah kejuruan musik, ditemukan bahwa genre musik pop menempati posisi teratas. Dengan kata lain, kecenderungan preferensi mengarah pada musik pop, disusul oleh genre rock, dan jazz. Untuk lebih jelasnya, perhatikan tabel di bawah ini.

Tabel 4. Preferensi Musik Responden Sekolah Menengah Umum

\begin{tabular}{|l|l|l|}
\hline \multicolumn{1}{|c|}{ Genre } & \multicolumn{1}{c|}{ Jumlah } & Persentase \\
\hline Pop & 59 orang & $83,01 \%$ \\
\hline Rock & 43 orang & $60,56 \%$ \\
\hline Keroncong & 2 orang & $2,82 \%$ \\
\hline Dangdut & 1 orang & $1,41 \%$ \\
\hline Campursari & 1 orang & $1,41 \%$ \\
\hline Tradisional & 4 orang & $5,63 \%$ \\
\hline Jazz & 11 orang & $15,49 \%$ \\
\hline Genre lain & 1 orang & $1,41 \%$ \\
\hline Ska \& pop rock & 1 orang & $1,41 \%$ \\
\hline Pop alternative & 2 orang & $2,82 \%$ \\
\hline R \& B & 3 orang & $4,23 \%$ \\
\hline $\begin{array}{l}\text { Deathmetal, } \\
\text { metalcore, } \\
\text { southernrock, } \\
\text { Christian rock, }\end{array}$ & & \\
\hline
\end{tabular}

\begin{tabular}{|l|l|l|}
\hline $\begin{array}{l}\text { screamd, } \\
\text { Sweetcore }\end{array}$ & & \\
\hline Japan Rock & 2 orang & $2,82 \%$ \\
\hline Sweet core & 1 orang & $1,41 \%$ \\
\hline Acoustic & 3 orang & $4,23 \%$ \\
\hline Rohani & 1 & $1,41 \%$ \\
\hline
\end{tabular}

Berdasarkan hasil yang diperoleh dari studi ini, maka pertanyaan yang muncul adalah: mengapa musik pop $^{3}$ begitu digandrungi oleh kalangan remaja-preferensi musik di kalangan remaja mengarah pada jenis musik pop? Faktor-faktor apa saja yang menimbulkan kecenderungan ini? Preferensi atau selera terhadap suatu objek pada dasarnya ditentukan oleh sejumlah faktor. Sebagai contoh, Bourdieu (1984:1) mengajukan pendapat bahwa preferensi seseorang terhadap karya sastra lukisan, ataupun musik, terkait erat dengat tingkat pendidikan dan asal-usul sosialnya. Kendatipun demikian, pandangan Bourdieu ini seolah mengabaikan bahwa suatu objek (misalnya karya sastra, lukisan, atau musik) memiliki kekuatan dalam dirinya sendiri. Dengan kata lain, suatu objek telah memiliki nilai dalam dirinya. Ada beberapa faktor yang mempengaruhi pandangan seseorang terhadap objek yang diterimanya, namun yang terutama adalah faktor pengalaman masa lalunya (Turino, 2008:9). Scherer dan Zentner (2001), mengemukakan bahwa hubungan antara musik dan emosi, pengalaman emosional ketika mendengarkan musik, ditentukan oleh empat faktor, yakni faktor struktural musik, faktor pertunjukan musik, faktor pendengar, dan faktor 
kontekstual (dikutip dari Huang, Wu \& Lin, t.t.:2). Artinya, interaksi antara musik dan pendengar ketika proses mendengarkan berlangsung merupakan sebuah peristiwa yang kompleks, dan disebabkan oleh berbagai faktor.

Pemaparan data temuan di atas menunjukkan bahwa latar belakang pendidikan dan sosial seseorang tidak begitu mempengaruhi preferensi musiknya. Pembentukan preferensi, seperti yang ditemukan dalam studi ini, juga dilatarbelakangi oleh 'kekuatan' yang dimiliki oleh musik itu sendiri dalam memunculkan ketertarikan para pendengarnya. Oleh karena itu, permasalahan ini akan dianalisis menggunakan beberapa konsep dan teori, sehingga diharapkan hasil yang diperoleh dapat lebih akurat.

Secara ringkas, faktor-faktor di balik preferensi terhadap suatu objek bersifat arbitrer, karena tiap orang yang memiliki preferensi terhadap suatu objek memiliki alasan masingmasing mengapa mereka memiliki objek tersebut. Kendatipun demikian, penilaian terkait faktor-faktor di balik preferensi seseorang terhadap suatu objek tidak boleh dilepaskan dari nilai objektif yang dimiliki oleh objek tersebut. Seorang pendengar musik terutama dibentuk preferensinya atas dasar pengetahuan terhadap musik dan konten dari musik itu sendiri (Pauws, 2000:33). Oleh karena itu, untuk menganalisis permasalahan preferensi musik dalam studi ini, penulis menggunakan konsep yang diajukan oleh R. von Appen dalam artikelnya yang berjudul "On the Aesthetics of Popular Music" (2007), yakni bahwa persepsi estetika atau preferensi terhadap suatu objekdalam hal ini musik-dapat dikategorikan menjadi tiga, yakni (1) persepsi estetika kontemplasi (karena kebentukannya), (2) persepsi estetika korespondensi (karena kesesuaian musik yang didengar dengan kehidupan sehari-hari si pendengar), serta (3) persepsi estetika imajinatif (karena makna dari musik itu). Jika dicermati, konsep von Appen ini mencakup penilaian terhadap musik itu sendiri dan juga terhadap pendengar musik.

Persepsi estetika kontemplasi dapat dikategorikan sebagai bentuk penilaian subjektif, sebab, nilai objektif dari musik-lah yang membangun ketertarikan seseorang terhadap musik tersebut. Pernahkah anda menyukai musik ketika pertama kali mendengarkannya, dan musik itu memiliki gaya yang berbeda dengan musik yang anda dengarkan seharihari? Apakah orang Indonesia yang menyukai sebuah lagu berbahasa asing benar-benar mengerti apa isi lirik lagu tersebut? Singkatnya, apa yang membuat seseorang langsung tertarik ketika mendengarkan sebuah musik yang sama sekali tidak familiar, dan mengapa seseorang menyukai sebuah lagu tanpa memahami isi atau pesan yang disampaikan oleh lagu tersebut? Hal ini antara lain disebabkan karena elemen-elemen musikal yang didengarkan memberikan rangsangan 'positif' terhadap organ-organ 
pendengaran dan persepsi pendengarnya.

Kecenderungan preferensi musik yang mengarah pada jenis musik pop, jika ditinjau dari konsep persepsi estetika kontemplasi yang diajukan oleh R. von Appen, berarti disebabkan oleh karakteristik formal (kebentukan) dari musik tersebut. Dengan demikian, pertanyaannya adalah bagaimana karakteristik formal dari musik pop? Kiranya cukup sulit untuk menjawab pertanyaan ini. Kendatipun demikian, yang dapat dilakukan adalah melihat unsur-unsur musik pop secara general. Ada beberapa unsur yang dapat dicermati terkait permasalahan ini, misalnya ritme maupun bentuk repertoarrepertoarnya. Berikut ini adalah unsur-unsur musik yang mempengaruhi ketertarikan responden menurut hasil yang diperoleh dari penelitian.

Tabel 5. Unsur yang disukai dari Musik

\begin{tabular}{|l|l|}
\hline \multicolumn{1}{|c|}{ Unsur Musik } & Persen \\
\hline Lirik & $71,43 \%$ \\
\hline Melodi & $54,76 \%$ \\
\hline Ritme & $28,57 \%$ \\
\hline
\end{tabular}

Berdasarkan data temuan di atas, dapat disimpulkan bahwa preferensi terhadap musik terutama terkait dengan isi lagu. Hal ini berarti menunjukkan bahwa korespondensi (kesesuaian) antara musik/lagu dan pendengar menjadi faktor yang paling berpengaruh. Melodi menempati posisi kedua sebagai faktor yang berpengaruh memunculkan keter- tarikan seseorang terhadap musik. Pola melodi yang ditemui dalam musik pop secara garis besar dapat dikategorikan ke dalam dua jenis, yakni mayor dan minor, namun keduanya dapat mencakup berbagai kesan bagi pendengarnya. Demikian pula halnya dengan tempo. Sebagai contoh, musik bertempo cepat dengan tangganada mayor memunculkan kesan gembira, sementara tangganada minor memunculkan kesan sedih.

Tabel 6. Karakteristik Musik/Lagu yang disukai

\begin{tabular}{|c|c|}
\hline \multicolumn{1}{|c|}{ Karakteristik } & Persentase \\
\hline Cepat dan Menghentak & $50 \%$ \\
\hline Lambat dan Mengalun & $59,52 \%$ \\
\hline
\end{tabular}

Sejauh ini, belum ditemukan literatur yang menyebutkan secara eksplisit unsur-unsur musik seperti apa yang memiliki kemenarikan (appeal) bagi pendengarnya. Kiranya sulit untuk ditemukan suatu parameter baku terkait permasalahan ini, sebab bagaimana persepsi suatu musik atau suatu objek sangat tergantung dengan pengalaman dan tingkat pengetahuan pendengarnya. Kendatipun demikian, Cornelius Cardew mengemukakan bahwa kemenarikan suatu repertoar terletak pada

(1) Its duration, and proportional to that (2) the variation within the uniform repetition (3) the stress imposed on the single performer and through him on the audience ... These elements occur rather in spite of the instructions, although 
naturally they are the result of them. What listener can hear and appreciate are the errors in the interpretation. If the piece were performed by a machine this interest would disappear and with it the composition (Hamilton, 2007:137).

Permasalahan kebentukan dapat ditinjau dari sudut pandang formalisme, yang mengungkapkan bahwa bentuk (form), sebagai lawan dari konten, makna, representasi atau tujuan ekstrinsik, merupakan elemen utama yang membentuk nilai estetika (Hamilton, 2007:71). Oleh karenanya, seperti yang diungkapkan oleh Kant, penilaian murni yang membentuk selera secara eksklusif dimunculkan oleh bentuk objek atau representasinya, sedangkan penilaian yang tidak murni dipengaruhi oleh berbagai faktor, misalnya keha-ngatan atau emosi (Hamilton, 2007:71-72). Pandangan formalisme dan Kant tampak sangat menekankan arti penting dari objek, dan mengabaikan peran subjek dalam penerimaan objek tersebut.

Jenis persepsi yang kedua, yakni persepsi estetika korespondensi, dapat dikategorikan sebagai bentuk penilaian yang sifatnya objektifsubjektif. Seseorang menyukai musik karena musik tersebut memiliki kesesuaian dengan kehidupan seseorang sehari-hari. Elemen-elemen dalam musik yang seseorang dengarkan itu-terutama lirik-nya, selain juga pola-pola melodi, ritmis, dan elemen-elemen musikal lainsejalan dengan pengalaman pende- ngarnya, merepresentasikan relitas yang seseorang alami, atau telah familiar dengan si pendengar. Secara ringkas, persepsi estetika korespondensi merujuk pada keadaan dimana preferensi, dalam hal ini preferensi musik, terbentuk karena adanya kesesuaian antara musikdalam hal ini konten musik-dengan kehidupan pendengarnya. Dalam konteks ini, musik merupakan tanda indeksikal. Kendatipun demikian, efek (yakni makna) dari tanda-tanda indeksikal, termasuk yang musik, tidak dapat diprediksi atau bersifat arbitrer, sebab sangat bergan-tung pada pengalaman masa lalu (past experiences) pendengarnya. Pengalaman-pengalaman masa lalu yang berbeda muncul terutama karena para pendengar musik kemungkinan berasal dari kelompok sosial dan kultural yang berbeda (Turino, 2008: 9).

Berdasarkan data yang diperoleh dari para partisipan, musik (dalam hal ini lagu, yakni musik yang menggunakan lirik) yang mereka sukai, yakni terutama musik pop, adalah yang bertemakan percintaan. Selain itu, lagu-lagu yang bertemakan persahabatan, kritik sosial dan nasionalisme juga disukai meskipun tidak dominan. Sejauh ini, telah ada literatur yang mengungkapkan secara eksplisit bahwa remaja identik dengan dunia percintaan, seksualitas, dan persoalan-persoalan identitas (missalnya, Mulder, 2008:7). Diperkuat dengan data temuan dari studi ini, dapat ditunjukkan bahwa remaja lekat 
dengan hal-hal yang bertemakan percintaan. Kesimpulan ini dapat dikemukakan karena, seperti yang dikemukakan oleh Felicity Baker dan William Bor, bahwa

Music fulfils a range of functions for human beings, especially so for adolescents. Musicllyrics can reflect a range of personal adolescent issues including identity, dependenceindependence, separatenessconnect-edness, values, and perception of the self. Furthermore, music aids resistance to authority, development of peer relationships, and learning about issues not communicated by their significant adults. In addition, music is said to regulate emotions by temporarily allowing an escape from thoughts and feelings or validating thoughts and feelings, and releasing pent up emotions, anxiety, energy and anger. While it is clear music is a significant part of the lives of adolescents, the evidence that certain music styles are linked with a range of psychological attributesneeds elaboration (2008:285).

Musik yang digemari oleh kalangan remaja, seperti yang ditunjukkan oleh studi ini, dapat diasumsikan sebagai refleksi dari kondisi-kondisi yang mereka alami. Kegandrungan atau preferensi terhadap jenis musik pop merefleksikan berbagai persoalan yang dialami oleh mereka yang termasuk dalam kategori remaja. Data temuan studi ini mendapati bahwa responden terutama menyukai musik yang liriknya bertemakan percintaan (romance). Untuk lebih jelasnya, perhatikan tabel di bawah ini.

Tabel 7. Tema Lirik yang Disukai

\begin{tabular}{|l|c|}
\hline \multicolumn{1}{|c|}{ Tema Lirik } & Persen \\
\hline Cinta & $73,81 \%$ \\
\hline Sosial & $16,67 \%$ \\
\hline Persahabatan & $9,52 \%$ \\
\hline Rohani & $4,76 \%$ \\
\hline Kehidupan & $9,52 \%$ \\
\hline Nasionalisme & $11,9 \%$ \\
\hline
\end{tabular}

Hal ini juga dapat ditinjau dengan konsep 'homologi' yang diajukan oleh Willis (1978:189). Yang dimaksud dengan homologi adalah keterkaitan suatu kebudayaan yang hidup di suatu tempat sebagai serangkaian 'relasi konstitutif'dengan 'objek, artefak, institusi dan praktik sistematis kebudayaankebudayaan lain yang mengitarinya.' Dengan kata lain, homologi mengisyaratkan bahwa suatu praktik kultural sudah semestinya dipahami dalam konteksnya, agar maknanya dapat dipahami. Berkenaan dengan digemarinya musik pop di kalangan remaja, maka tidak dapat dilepaskan antara musik pop dengan domain-domain lain dalam praktik-praktik kehidupan remaja, misalnya pandangan dunia mereka, cara berpikir, orientasi, kondisi psikologis, pergaulan seharihari, dan sebagainya. Selain merupakan refleksi dari kondisi yang sedang dialami, musik pop, dalam produksinya ${ }^{4}$ di kalangan remaja juga dapat dikategorikan sebagai wahana 
untuk merepresentasikan kondisi mereka. Hal ini mengindikasikan bahwa musik pop, seperti halnya musik-musik lain secara general, memiliki fungsi ekspresi emosional (lihat, misalnya, Merriam, 1964; DeNora, 2003; Harré, 1997).

Korespondensi juga dapat dilihat dari kegunaan musik bagi pendengarnya. Ketika sesuatu berarti bagi seseorang, maka ia akan membuat atau mempertahankan apa yang dimilikinya itu. Sebagai contoh, seseorang memiliki kendaraan karena kendaraan itu bisa mempermudah mobilitasnya, atau memenuhi kebuthan-kebutuhan lainnya. Dewasa ini, musik memiliki berbagai kegunaan bagi pendengarnya, sehingga musik itu tetap didengarkan. Studi ini menunjukkan beberapa kegunaan musik bagi pendengarnya, seperti yang ditunjukkan oleh kapan musik didengarkan. Perhatikan tabel di bawah ini.

Tabel 8. Saat-saat dimana Musik didengarkan

\begin{tabular}{|l|c|}
\hline \multicolumn{1}{|c|}{ Saat } & Persen \\
\hline Belajar/mengerjakan sesuatu & $33,33 \%$ \\
\hline Menjelang tidur & $38,1 \%$ \\
\hline Santai & $80,95 \%$ \\
\hline Senang & $47,62 \%$ \\
\hline Sedih & $40,48 \%$ \\
\hline
\end{tabular}

Data di atas menunjukkan bahwa musik merupakan media untuk menuju keadaan rileks, mengiringi suasana senang, sedih, ataupun sebagai pengantar tidur. Dalam konteks ini, tampak jelas bahwa musik terkait dengan kondisi psikologis seseorang. Kendatipun demikian, untuk memahami permasalahan ini kiranya dibutuhkan penelitian yang komprehensif. Terlepas dari itu, tampak pula bahwa musik banyak 'mengiringi' aktivitas dalam kehidupan sehari-hari. Artinya, musik telah menjadi bagian yang sangat dekat dengan kehidupan seseorang, terutama dewasa ini, ketika kemajuan teknologi memberikan berbagai kemudahan untuk mendengarkan musik dalam berbagai situasi dan kondisi.

Persepsi ketiga, yakni persepsi estetika imajinatif, dapat dikategorikan sebagai penilaian yang sifatnya subjektif. R. von Appen mengemukakan bahwa jenis persepsi ini mengarah kepada preferensi yang ditimbulkan oleh makna dari musik. Tidak semua bunyi dikategorikan sebagai 'musik', dan hal ini terkait dengan konstruksi, terutama konstruksi dalam masyarakat, terkait apa yang dikategorikan sebagai 'musik'. Sebagai contoh, orang menganggap kicauan burung itu indah, tetapi kicauan burung itu bukanlah 'musik' yang indah saat seseorang tidak menganggap kicauan burung sebagai musik. Singkatnya, kicauan burung adalah 'bunyi yang indah', tetapi belum tentu kicauan burung tersebut dianggap sebagai 'musik yang indah'. Dengan demikian, preferensi terhadap musik bergantung pada konstruksi tentang 'apa yang disebut musik dan apa yang bukan musik'. Selain itu, apa yang dikategorikan sebagai 'indah' dan 'tidak indah' sebagian juga 
merupakan hasil dari konstruksi, terutama konstruksi yang sifatnya sosial. Singkatnya, jenis persepsi estetika ini berbentuk pemahaman terhadap musik yang didengarkan.

Pemahaman terhadap musik seringkali diawali oleh lirik, sementara nyanyian dan musik memberikan dimensi atmosferis dan emosional serta signifikansi personal terhadap konten musik itu (von Appen, 2007:17). R. Von Appen melanjutkan,

The combination and interplay of musical and lyrical parameters stimulates the imagination to discover links between them and asso-ciate them with an underlying concept. But apart from the peculiar fascination of decoding music as a symbol, such a perception of music as art contributes much to our orientation in the world. Whether we are able to name a semantic substance as a unifying principle or not: attention to artistically formed appearance permits encounters and involvement with strange experiences and outlooks in a sensual richness that is not possible outside art. Art may summarize and highlight individual experience and thus ensure us of our own outlook, or it can break up "conventionally settled modes of un-derstanding, experience and percep-tion" ... and thus open up new perspectives (2007:19).
Berkenaan dengan makna musik, maka dalam konteks ini musik ditempatkan sebagai simbol. Namun perlu diingat bahwa interpretasi terhadap sebuah simbol sifatnya arbitrer (semena-mena), dan terutama sangat bergantung pada latar belakang interpretannya. Berkaitan dengan musik pop, permasalahan makna terutama berangkat dari liriknya. Hal ini disebabkan karena tampaknya sulit untuk memaknai bunyi-bunyi musikal (selain lirik), dan, musik-musik pop yang marak saat ini seluruhnya menggunakan lirik. Lirik-lirik yang digemari, seperti telah disinggung di atas, menunjukkan kecenderungan pada lirik yang bertemakan percintaan. Musik pop yang didengarkan, dalam konteks ini, merupakan wahana untuk menghadirkan dunia pendengarnya, yaitu remaja.

Selanjutnya, penulis akan mendiskusikan fenomena popularisasi jenis-jenis musik tertentu, yang umumnya diwacanakan sebagai fenomena musik popular. Dalam konteks yang lebih luas, permasalahan ini merupakan bagian dari kemunculan budaya popular dewasa ini.'Populer,' bagi sebagian orang, berarti sesuatu yang menarik bagi masyarakat; bagi sebagian lainnya, istilah ini memiliki arti 'sesuatu yang berangkat dari masyarakat' (Shuker, 2001:3). Arti yang pertama secara umum digunakan untuk mengacu pada produk-produk yang diproduksi secara komersial, sementara arti yang kedua mengacu pada bentuk-bentuk 
produk budaya 'yang bersifat kerakyatan.' Berkenaan dengan musik, perbedaan arti ini memunculkan apa yang disebut dengan musik rakyat dan musik yang berorientasi chart. Hal ini senada dengan yang diungkapkan oleh banyak pakar, bahwa komersialisasi adalah kunci untuk memahami musik populer: 'Ketika seseorang membicarakan musik populer, seseorang membicarakan musik yang berorientasi komersial (Burnett, 1996:35, seperti dikutipoleh Shuker, 2001:6). Dengan demikian, paling tidak untuk kepentingan dalam tulisan ini, musik populer diartikan sebagai musik yang berorientasi komersial atau musik yang dikomersialisasikan, terutama lewat media massa.Sejauh ini, teori-teori tentang efek media mengemukakan bahwa media massa mempengaruhi pemikiran, keyakinan, emosi, dan perilaku masyarakat; alhasil, ketika seseorang mendengarkan musik yang berisikan tentang kekerasan, maka ia akan bertindak dengan cara-cara yang lekat dengan kekerasanpula (Mulder, 2008:11).

Pembentukan preferensi musik masyarakat global dewasa ini dapat juga dipandang sebagai pengaruh media. Media massa yang saat ini dapat merambah ke berbagai penjuru dunia dan berbagai lapisan masyarakat dengan sangat mudah dan cepat merupakan wahana sosialisasi yang sangat efektif dan efisien untuk mengakrabkan musik dengan masyarakat. Kasus pembentukan preferensi musik dalam kait-annya dengan fenomena popularisasi musikbudaya populer, dalam konteks yang lebih luas-sangat tepat dipahami dengan menggunakan teori yang dikemukakan oleh Pierre Bourdieu (1984). Bourdieu mengemukakan bahwa preferensi terhadap produk kultural merupakan hasil dari sebuah proses panjang dan rumit: agen-agen (kapitalis, musisi, pendengar) yang bertarung dalam ranah, misalnya ranah musik populer, saling mengadu kekuatan modal ekonomi dan modal kultural yang dimiliki. Agen yang memiliki kekuatan modal ekonomi maupun modal kultural yang kuat-lah yang menjadi pemenangnya-ia berhak menentukan apa yang diproduksi dan didistribusikan kepada khalayak. Dalam kasus musik populer, yang menjadi pemenang dalam pertarungan di ranah ini adalah para kapitalis, yang dengan bebas melemparkan berbagai jenis musik, terutama pop, kepada khalayak untuk dikonsumsi.

Theodor Adorno

(2001 [1991]:98), seorang tokoh mazhab Frankfurt, mengemukakan bahwa karakterisitik musik populer adalah standarisasi. Mengapa demikian? Seperti telah dijelaskan terdahulu, bahwa musik populer merupakan musik yang berorientasi komersial, atau musik yang ditujukan sebagai konsumsi massa. Komersialisasi ini dimodali oleh para kapitalis, yakni mereka yang memiliki kekuatan modal untuk memproduksi. Selanjutnya, para kapitalis ini memiliki preferensi tertentu terkait jenis musik 
atau gaya musik apa yang akan mereka lempar ke pasaran. Dengan demikian, produk musik yang akan diterima oleh konsumen jelas merupakan produk yang sesuai dengan preferensi para kapitalis yang berkuasa dalam industri musik. Pada gilirannya, bukanlah sesuatu yang mustahil apabila masyarakat akan memiliki selera musik yang 'standar' (baca: sama).

Produksi massal musik berkat kemajuan teknologi hingga dapat dibuat dalam kemasan yang murah dan mudah diperoleh-kaset, CD, dan sebagainya-juga berpengaruh dalam pembentukan preferensi musik. Dewasa ini, mendengarkan musik telah menjadi bagian yang seolah tak terpisahkan dari kehidupan seharihari. Keadaan ini berbeda ketika musik belum direkam dan disebarluaskan dengan mudah. Dahulu, untuk bisa mendengarkan dan menyaksikan pertunjukan musik, seseorang harus mendatangi gedung pertunjukan, dan tidak jarang mengeluarkan sejumlah biaya agar dapat menonton pertunjukan tersebut. Hal ini mengindikasikan bahwa akses seseorang terhadap musik masih sangat terbatas dan cukup sulit. Hal ini mengarah pada preferensi terhadap satu atau sedikit jenis musik saja. Keadaan ini menjadi berbeda ketika produksi musik dalam bentuk massal mulai dilakukan. Saat ini, seseorang dapat mengakses berbagai jenis musik dengan mudah berkat kemajuan teknologi media dan informasi yang sangat pesat tanpa mengeluarkan banyak biaya dan aturan-aturan yang terlalu rumit (misalnya etika-etika tertentu ketika menghadiri sebuah konser). Kaset dan CD dapat dijumpai dengan sangat mudah di tempat-tempat tertentu. Bahkan, kehadiran CD bajakan, missalnya, semakin mempermudah akses seseorang untuk mendengarkan musik karena ia dapat membelinya dengan harga yang jauh relatif lebih murah. Selain itu, keberadaan internet yang entah disengaja atau tidak, menyediakan nyaris semua musik terbaru dan dapat diunduh (downloadable) secara cuma-cuma.

Kemudahan mengakses berbagai jenis musik dengan sangat mudah menyebabkan seseorang dapat mendengarkan berbagai jenis musik dengan mudah pula. Hal ini antara lain bermuara pada fenomena yang oleh Bennet dan rekan-rekannya (2009) disebut sebagai 'omnivora musik.' Keadaan ini juga dijumpai dalam studi ini. Partisipan menunjukan kecenderungan menyukai beberapa jenis musik sekaligus, meskipun yang mayoritas digemari adalah jenis musik pop.

Penjelasan di atas menunjukkan bahwa preferensi musik pada dasarnya merupakan hasil dari interaksi dua arah antara objek (musik itu sendiri) dengan subjek (pendengar).Artinya, masing masing kutub ini-objek dan subjekmemiliki kekuatan untuk membentuk preferensi. Jika dicermati kembali, latar belakang pendengar, seperti yang ditunjukkan oleh data temuan, 
bukanlah faktor yang pertama dan utama dalam pembentukan preferensi musik. Pendapat Bourdieu yang menyatakan bahwa preferensi merupakan hasil dari habitus yang terbentuk dari proses pertarungan antar agen-agen, sejauh ini tampak mengesampingkan nilai objektif yang dimiliki oleh suatu objek. Dengan demikian, jika mengikuti pendapat Bourdieu ini, maka preferensi musik seseorang terhadap jenis musik tertentu merupakan hasil dari faktorfaktor eksternal di luar musik itu sendiri. Pandangan ini seolah-olah mengabaikan bahwa suatu objek telah memiliki nilai objektif sebelum ia dinilai.

Studi ini menunjukkan bahwa sejauh ini preferensi, yang terutama mengarah pada jenis musik pop, juga turut dilatarbelakangi oleh nilai objektif dari musik itu sendiri. Nilai objektif, dalam diskusi ini, penulis gunakan untuk menyebutkan aspek formal (kebentukan) dari musik. Lirik dan melodi, misalnya. Memiliki kekuatan untuk memunculkan ketertarikan pada pendengarnya. Berdasarkan hal ini, maka penulis menggunakan teori lain untuk menganalisis permasalahan preferensi musik yang merupakan fokus dari studi ini. Jika teori yang dikemukakan oleh Bourdieu mengabaikan nilai objektif musik, maka kiranya perlu mencari cara untuk membahas sisi yang tidak secara khusus dijadikan perhatian oleh Bourdieu, yakni aspek formal (kebentukan) musik. R. von Appen mengajukan pendapat bahwa persepsi estetika atau preferensi terhadap suatu jenis musik disebabkan oleh tiga hal, yakni bahwa musik, secara tampilannya (kedengarannya) langsung memunculkan ketertarikan pendengarnya; karena musik yang didengar sesuai dengan pengalaman hidup sehari-hari; dan karena makna dari musik bagi pendengarnya. Pendapat yang dikemukakan oleh von Appen ini mempertimbangkan dua kutub yang berinteraksi dalam pembentukan preferensi terhadap suatu jenis musik, yakni objek (musik) dan subjek (pendengar).

Permasalahan lain yang juga dapat dikatkan dengan preferensi musik adalah fenomena musik populer, yakni popularisasi jenis-jenis musik tertentu. Peran media dewasa ini, yang begitu dalam masuk ke dalam kehidupan masyarakat, menjadi media 'sosialisasi' untuk jenis musik tertentu dengan sangat efektif dan efisien. Musik, saat ini, sudah menjadi bagian tak terpisahkan dari kehidupan sehari-hari. Seseorang dapat sepanjang hari mendengarkan musik lewat media elektronik yang dewasa ini semakin canggih saja.

Media massa, terutama radio dan televisi, dengan programprogram musik yang ditayangkan, juga merupakan wahana yang dapat membentuk preferensi musik terhadap jenis musik tertentu. Program-program Top 10 atau Top 40, misalnya, kemungkinan dapat membangun image suatu jenis musik yang menduduki peringkat teratas. 
Ketika suatu jenis musik menduduki peringkat teratas (baik karena sungguh-sungguh dipilih oleh para pemirsa ataupun karena manipulasi tertentu oleh pihak produsen dan broadcaster), maka masyarakat seolaholah dikonstruksi untuk menyukai musik itu. Jika orang-orang tertentu tidak menaruh minat yang sama dengan yang ditunjukkan oleh chart di radio-radio dan televise, mereka akan dianggap aneh, tidak mengikuti tren dan ketinggalan jaman. Dalam konteks ini, preferensi musik dapat dipandang sebagai suatu bentuk konformitas sosial (social comformity).

\section{Penutup}

Studi ini menemukan bahwa kecenderungan selera musik di kalangan remaja mengarah pada jenis musik pop. Kendatipun demikian, pada dasarnya seseorang tidak hanya mendengarkan musik yang menjadi preferensi utamanya, melainkan juga 'mengkonsumsi' jenis-jenis musik lain, hanya saja, jenis musik pop menduduki tempat teratas dalam preferensi musik. Kecenderungan pemilihan musik pop sebagai preferensi di kalangan remaja dilatorbelakangi oleh beberapa faktor, yaitu nilai objektif dari musik pop itu sendiri, kemampuan musik pop untuk merepresentasikan berbagai kondisi yang dialami olah remaja, serta makna dari musik itu bagi kalangan remaja. Kendatipun demikian, ketiga faktor ini pada dasarnya tidak dapat dipisahkan secara kaku. Musik pop, yang selalu menggunakan lirik, serta berbagai karakteristik musikalnya, mampu memenuhi kebutuhan pendengar. Tempo musik yang lambat mengalun maupun yang cepat dan menghentak mampu mengakomodir kebutuhan emosional remaja sebagai pendengarnya. Demikian juga tangganada yang digunakan, misalnya, mampu menghadirkan nuansa kesenangan maupun kebahagian, yang merupakan perasaan dasar manusia, termasuk remaja.

Lirik-lirik musik pop juga dapat menjadi wahana untuk merefleksikan kondisi sosio-psikologis para remaja. Lirik-lirik yang sangat lekat dengan tema percintaan, misalnya, sangat mudah diterima oleh remaja, karena dalam fase ini, mereka memang dekat dengan persoalan percintaan, seksualitas, dan identitas. Lebih jauh lagi, makna dari lagu-lagu yang dihadirkan oleh jenis musik pop sangat sesuai dengan kondisi remaja. Oleh karena itu, pemaknaan dari lagu-lagu tersebut dapat dilakukan dengan cukup mudah. Hal ini disebabkan karena makna tidak dapat dilepaskan dari konteks, dan tematema lagu yang diusung oleh musik pop sangat tepat diinterpretasikan dalam konteks remaja.

Jika kembali kepada pendapat Bourdieu, bahwa latar belakang tertentu (yaitu pendidikan dan sosial) mempengaruhi preferensi musik sesorang, temuan studi ini menunjukkan hal yang sedikit berbeda. Studi ini mendapati bahwa responden yang berasal dari sekolah kejuruan musik (berlatar belakang pengetahuan 
musik) dan sekolah menengah umum (yang umumnya tidak berlatar belakang pengetahuan musik) memiliki kecenderungan preferensi yang nyaris serupa. Singkatnya, prefernsi musik tidak hanya dibentuk oleh latar belakang pendidikan dan sosial, melainkan juga oleh kekuatan yang dimiliki oleh musik itu sendiri, serta kemampuan musik itu untuk memenuhi kebutuhan pendengarnya. Di kalangan remaja, faktor utama yang dipenuhi oleh musik pop adalah karena musik ini mampu menjadi saluran emosi dan representasi diri pendengarnya.

Faktor lain yang juga berpengaruh dalam preferensi musik dewasa ini adalah fenomena popularisasi musik-media massa sangat berpengaruh dalam pembentukan preferensi. Media massa menjadi wahana yang efektif dan efisien untuk 'mencekoki' masyarakat dengan musik. Media massa membuat musik menjadi bagian yang tak terlepaskan dar kehidupan seharihari. Televisi dan radio merupakan media yang paling memiliki pengaruh kuat dalam pembentukan preferensi masyarakat. Program Top 10 atau Top 40, misalnya, secara tidak langsung mengkostruksi pandangan masyarakat terhadap mana musik yang 'bagus' dan yang 'tidak bagus.' Selain itu, jenis musik yang homogen dalam tayangan-tayangan media selanjutnya akan menyeragamkan juga kebiasaan mendengar (listening habit) masyarakat.
Studi ini pada dasarnya masih sangat terbatas dalam lingkup yang kecil, sehingga kesimpulan-kesimpulan yang berhasil dibuat umumnya masih bersifat sementara. Oleh karena itu, kiranya perlu dilakukan studistudi lain tentang permasalahan serupa agar data-data yang diperoleh dapat digunakan untuk membuat generalisasi. Selanjutnya, studi-studi empiris tentang preferensi musik masih perlu dilakukan dengan lebih komprehensif, agar berbagai permasalahan yang mendasari fenomena ini dapat dipahami dengan semakin mendalam.

Catatan:

1Pelajar SMU memiliki kategori umur yang jelas, berbeda halnya yang ditemui di bangku universitas atau perguruan tinggi. Pelajar SMA kemungkinan besar, dan hampir pasti, berada pada teba usia antara 15-17 tahun, sedangkan di perguruan tinggi, usia anggotanya (mahasiswa) sangat heterogen.

${ }^{2}$ Dalam penelitian ini, satu orang responden tidak hanya diperbolehkan untuk memilih satu genre musik yang menjadi preferensinya. Sebaliknya, seorang responden diperbolehkan untuk memilih lebih dari satu genre musik. Hal ini dimaksudkan untuk melihat apakah terjadi kecenderungan 'omnivora' musik.

${ }^{3}$ Istilah musik pop, yang merupakan jenis musik dengan persentase terbanyak sebagai preferensi, kiranya perlu diperjelas maknanya. Konsep musik pop berbeda dengan konsep musik populer. Gammond mengemukakan bahwa "While the use of the word 'popular' in relation to the lighter forms of music goes back to the mid-19th century, the abbreviation 'pop' was not in use as a generic term until the 1950s when it was adopted as the umbrella name for a special kind of musical 
product aimed at a teenage market (1991:457, seperti dikutip oleh Shuker, 2002: 225). Musik pop merupakan genre musik, yang terutama ditujukan untuk kalangan remaja. Kendatipun demikian, penggunaan istilah 'musik pop' dan 'musik populer' seringkali tumpang tindih. Musik populer adalah musik yang diorentasikan untuk tujuan komersialisasi, sedangkan musik pop hanya merupakan salah satu genre yang dewasa ini sangat populer.

${ }^{4}$ Yang dimaksud dengan produksi di sini adalah ketika musik dimainkan secara aktif (music-making) dalam kehidupan sehari-hari (misalnya sekedar menyanyikan atau memainkannya di sela-sela berbagai aktifitas lainnya), tidak harus diproduksi untuk kemudian direkam dan didistribusikan ke pasar sebagai hasil industri.

\section{Referensi}

Bandem, I Made. 2000. Metodologi Penciptaan Seni. Yogyakarta: Program Pasca Sarjana ISI Yogyakarta.

Budhisantoso, S. 1980. "Kesenian Dan Nilai-Nilai Budaya" dalam Analisis Kebudayaan. Jakarta: Departemen Dan Kebudayaan, Tahun I nomor 2.

Hardjana, Suka. 1983. Estetika Musik. Jakarta:

Departemen Pendidikan dan Kebudayaan Direktorat Jendral Pendidikan Dasar dan Menengah.

Haviland, William A. Antropologi Jilid 2. Jakarta: Erlangga, 1993. Terjemahan R.G. Soekatijo.

Kaemmer, John. 1993. Music In Human Life: Anthropology Perspective on Mu-sic. Austin: University Of Texas Press.

Kartodirdjo, Sartono. 1993. Pendekatan Ilmu Sosial Dalam Metodologi
Sejarah. Jakarta: PT. Gramedia Pustaka Utama.

Kuntowijoyo, (ed.) 1986-1987. Tema Islam Dalam Pertunjukan Rakyat Jawa: Kajian Aspek Sosial, Keagamaan, Dan Kesenian. Yogyakarta: Javanologi.

Lindsay, Jennifer. 1991. Klasik Kitsch Kontemporer Sebuah Studi Tentang Seni Pertunjukan Jawa. Yogyakarta: Gadja Mada University Press, (Diterjemahkan oleh Nin Bakdi Sumanto).

Malinowski. 1987. “Teori Fungsional dan Struktural" dalam Koentjaraningrat Teori Antropologi. Jakarta: Universitas Indonesia Press.

Poerwadarminta, W.J.S. 1976. Kamus Umum Bahasa Indonesia. Jakarta: PN Balai Pustaka.

Rouget, Gilbert. 1985. Music And Trance A theory of the Relations Between Music and possession. Chicago And London: The University of Chicago Press.

Soedarsono, R.M. 1976. Tari-tarian Rakyat di Daerah Istimewa Yogyakarta. Yogyakarta: Akademi Seni Tari Indonesia. 1999. Metodologi

Penelitian Seni Pertunjukan dan Seni Rupa. Bandung: Masyarakat Seni Pertunjukan Indonesia.

Soedarso Sp. 1990. Sebuah Pengantar Untuk Apresiasi Seni. Yogyakarta: Suku Dayar Sana. 